dr hab. Małgorzata Karpińska-Krakowiak

Uniwersytet Łódzki

Wydział Studiów Międzynarodowych i Politologicznych

Katedra Marketingu Międzynarodowego i Dystrybucji

ROZDZIAt 1

\title{
ANIMIZACJA W KOMUNIKACJI MARKETINGOWEJ MAREK - WYNIKI ANALIZY ZAWARTOŚCI PRZEKAZÓW REKLAMOWYCH ${ }^{1}$
}

\section{WPROWADZENIE}

Na gruncie komunikacji marketingowej animizację należy rozumieć jako szczególny środek narracyjny stosowany w przekazach reklamowych, mający na celu stworzenie wrażenia wśród konsumentów, że marka bądź produkt to istota żywa lub wręcz podobna do człowieka. Mimo dużej popularności koncepcji ożywiania marki w reklamie ${ }^{2}$ nadal brakuje uniwersalnej definicji animizacji i nie wiadomo, jak często jest ona stosowana w komunikacji marketingowej przedsiębiorstw.

${ }^{1}$ Badania zaprezentowane $\mathrm{w}$ niniejszym tekście stanowią część szerszego projektu badawczego realizowanego dzięki wsparciu Narodowego Centrum Nauki (2016/21/B/HS4/00658). Przedstawiona tu konceptualizacja animizmu i wskazówek animizacyjnych (która pochodzi z 2018 r.) została szczegółowo przedstawiona w tekście przygotowanym przeze mnie we współpracy z Martinem Eisendem (2019) Broken mirrors, black cats and animate brands - the effects of animism, animistic cues and superstitions on brand responses in social media, conference proceedings, ICORIA, University of Applied Sciences, Krems, Austria.

2 Por. S. Fournier, Consumers and their brands: Developing relationship theory in consumer research, "Journal of Consumer Research", 1998, 24(3), s. 343-373; M. Puzakova, H. Kwak, J. Rocereto, Pushing the Envelope of Brand and Personality: Antecedents and Moderators of Anthropomorphized Brands, „Advances in Consumer Research”, 2009, 36, s. 413-419; P. Aggarwal, A.L. McGill, Is That Car Smiling at Me? Schema Congruity as a Basis for Evaluating Anthropomorphized Products, „Journal of Consumer Research”, 2007, 34(4), s. 468-479; P. Aggarwal, A.L. McGill, When Brands Seem Human, Do Humans Act Like Brands? Automatic Behavioral Priming Effects of Brand Anthropomorphism, „Journal of Consumer Research”, 2012, 39(2), s. 307-323; A. Maeng, P. Aggarwal, Facing Dominance: Anthropomorphism and the Effect of Product Face Ratio on Consumer Preference, „Journal of Consumer Research”, 2017, 44(5), s. 1104-1122; M. Puzakova, H. Kwak, Should Anthropomorphized Brands Engage Customers? The Impact of Social Crowding on Brand Preferences, „Journal of Marketing”, 2017, 81(6), s. 99-115. 
Wielu autorów ${ }^{3}$ sugeruje, że praktycy marketingu często i chętnie sięgają po antropomorfizację oraz personifikację w kampaniach promocyjnych, lecz w literaturze nie ma konkretnych danych na poparcie tych stwierdzeń. Celem niniejszego tekstu jest zatem uporządkowanie dyskursu na temat animizacji marek, konceptualizacja oraz operacjonalizacja tego pojęcia, a także zbadanie częstotliwości stosowania tego zabiegu narracyjnego we współczesnych przekazach reklamowych.

\section{ANIMIZACJA - ISTOTA ZJAWISKA}

Animizacja (lub inaczej ożywienie) to figura retoryczna polegająca na przypisaniu przedmiotom lub zjawiskom cech charakterystycznych dla istot żywych. Przykładem mogą być takie wyrażenia jak „wicher zawył” i „nadzieja umarła”, ukazujące zjawisko pogodowe (wiatr) i konstrukt abstrakcyjny (nadzieja) jako elementy przyrody ożywionej. Animizacja jest terminem stosunkowo szerokim i obejmuje personifikację (uosobienie czy też antropomorfizację), która sprowadza się do nadawania właściwości ludzkich obiektom nieożywionym lub ideom (np. przedstawianie śmierci jako kościstej kobiety lub szkieletu). Oba pojęcia stanowią rodzaj środków retorycznych z grupy metafor, znajdujących zastosowanie nie tylko w przekazach tekstowych, lecz także audiowizualnych.

Animizacji nie należy mylić z animizmem, który odnosi się do skłonności ludzi do postrzegania świata w bardzo specyficzny sposób. Animizm bowiem to strategia percepcyjna polegająca na nadawaniu wybranym obiektom nieożywionym cech typowych dla organizmów żywych ${ }^{4}$; to błędne przekonanie jednostki, że niektóre z otaczających ją przedmiotów żyją i posiadają wolną wolę. Animizm był i jest stosowany przez ludzi pochodzących z różnych krajów i reprezentujących różne kultury ${ }^{6} \mathrm{w}$ celu oswojenia otoczenia, nadania mu znaczenia lub wartości symbolicznej ${ }^{7}$. Mimo że najsilniej objawia się wśród dzieci i słabnie z wiekiem",

${ }^{3}$ M.in.: S. Fournier, op.cit.; M. Puzakova, P. Aggarwal, Brands as Rivals: Consumer Pursuit of Distinctiveness and the Role of Brand Anthropomorphism, "Journal of Consumer Research”, 2018, DOI: 10.1093/jcr/ucy035; P. Aggarwal, A.L. McGill, op.cit.

${ }^{4}$ M. Delbaere, E. McQuarrie, B. Phillips, Personification in Advertising: Using a Visual Metaphor to Trigger Anthropomorphism, „Journal of Advertising”, 2011, 40, s. 121-130.

${ }^{5}$ J. Piaget, The Child's Conception of the World, Harcourt Brace, Nowy Jork 1929.

${ }^{6}$ R. Willerslev, Not animal, not not-animal: hunting, imitation and empathetic knowledge among the Siberian Yukaghirs, „Journal of the Royal Anthropological Institute”, 2004, 10(3), s. 629-652.

7 S. Guthrie, Faces in the clouds, Oxford University Press, 1993; S. Guthrie, Bottles are men, glasses are women: religion, gender, and secular objects, „Material Religion”, 2007, 3(1), s. 14-33.

${ }^{8}$ J. Piaget, The Child's Conception of the World, Routledge and Kegan Paul, Londyn 1951.

9 M. Bullock, Animism in childhood thinking: a new look at an old question, „Developmental Psychology", 1985, 21, s. 217-225; K. Inagaki, K. Sugiyama, Attributing human characteristics: developmental changes in over- and underattribution, „Cognitive Development”, 1988, 3, s. 55-70. 
nie znika całkowicie u osób dojrzałych ${ }^{10}$. A zatem w kontekście komunikacji marketingowej animizacja to zabieg retoryczny odnoszący się do marki w warstwie tekstowej lub audiowizualnej przekazu, natomiast animizm to sposób postrzegania marki przez odbiorcę. Innymi słowy, ukazanie postaci królika w reklamie Duracell stanowi przykład animizacji, ale nie animizmu ${ }^{11}$.

\section{WSKAZÓWKI ANIMIZACYJNE I ICH KATEGORYZACJA}

Dla reklamodawcy kluczowe pozostaje następujące pytanie: Jakie wskazówki można zastosować w przekazie, aby zasugerować konsumentowi, że marka żyje? Zgodnie z zaoferowaną przez Epleya, Waytza i Cacioppo ${ }^{12}$ teorią aktywacji wiedzy (knowledge activation theory), jak również według koncepcji teoretycznych z zakresu psychologii ewolucyjnej ${ }^{13}$, jednym z kluczowych warunków uruchamiających myślenie antropomorficzne wśród odbiorców jest wyposażenie obiektu nieożywionego w cechy fizyczne sugerujące jego ludzki charakter i czyniące go podobnym do ludzi. Najprostszym wówczas zabiegiem staje się próba nadania temu obiektowi (np. marce lub produktowi) takich atrybutów i kompetencji, które przynależą istotom żywym, jak np. ruch ${ }^{14}$, kształt $^{15}$, mimika twarzy i dźwięk ${ }^{16}$. Wiele firm korzysta z tych rozwiązań w swoich działaniach marketingowych m.in. przez nadanie nazwy sugerującej postać ludzką (Mr. Proper, Jan Niezbędny, margaryna Kasia), zastosowanie opakowania o kształcie ciała ludzkiego (butelka Coca-Coli), powoływanie ludzkich reprezentantów marki (np. Eva Longoria dla Sheba, Marek Kondrat dla ING) czy tworzenie animowanych bohaterów marki (np. potwór Głód dla Danio).

Istnieje grupa teorii, które wyrosły z założenia, że aktywacja myślenia animistycznego u odbiorcy nie wymaga wyposażenia obiektu nieożywionego w fizyczne

10 R. Parry, I. Stuart-Hamilton, Animism begins at forty: evidence that animism and other naive beliefs are established before the onset of old age, „Educational Gerontology”, 2010, 36, s. 1043-1050; L. McDonald, I. Stuart-Hamilton, The Meaning of Life: Animism in the Classificatory Skills of Older Adults, „International Journal of Aging and Human Development”, 2000, 51(3), s. 231-242.

${ }_{11}$ M. Avis, Anthropomorphism and Animism Theory in Branding, „Asia-Pacific Advances in Consumer Research", 2011, 9, s. 313-319.

12 N. Epley, A. Waytz, J. Cacioppo, On Seeing Human: A Three-Factor Theory of Anthropomorphism, „Psychological Review”, 2007, 114(4), s. 864-886.

13 Zob. rozważania De Bondt, Kerckhove i Geuens [w:] C. De Bondt, A. Van Kerckhove, M. Geuens, Look at that body! How anthropomorphic package shapes systematically appeal to consumers, „International Journal of Advertising”, 2018, DOI: 10.1080/02650487.2018.1470919.

${ }^{14}$ P. Tremoulet, J. Feldman, Perception of Animacy from the Motion of a Single Object, "Perception”, 2000, 29(8), s. 943-951; C. Morewedge, J. Preston, D. Wegner, Timescale Anthropomorphism in the Attribution of Mind, [working paper], Harvard University, Boston 2004.

15 S. Graham, D. Poulin-Dubois, Infants' Reliance on Shape to Generalize Novel Labels to Animate and Inanimate Objects, „Journal of Child Language”, 1999, 26(2), s. 295-320.

16 P. Aggarwal, A.L. McGill, op.cit. 
cechy istot żywych. Na przykład koncepcje obecności ludzkiej (human presence) i społecznej (social presence) zakładają, że wystarczy tak sformułować przekaz, aby jedynie stworzyć atmosferę interakcji społecznej i zasugerować kontakt z drugim człowiekiem ${ }^{17}$. Innymi słowy, nie jest konieczna fizyczna obecność ludzkiego interlokutora, by wytworzyć u konsumenta poczucie komunikacji z istotą żywą. Według nielicznych badań w tym obszarze wrażenie ludzkiej obecności może być wywołane nawet przez tak subtelny sygnał jak pismo odręczne ${ }^{18}$. Należy się zatem zastanowić, czy i jakie inne wskazówki animizacyjne mają podobne właściwości i mogą budować przekonanie wśród odbiorców, iż komunikująca się z nimi marka żyje.

Kluczowe różnice między obiektami nieożywionymi a ożywionymi nie sprowadzają się jedynie do umiejętności związanych z ruchem, mową i budową ciała. Istoty żywe posiadają szerokie spektrum własności odróżniających je od przyrody nieożywionej. Na przykład ludzie i zwierzęta tworzą własne porządki społeczno-kulturowe, mają własne rytuały i nawyki; potrafią się razem bawić, grać (indywidualnie lub $\mathrm{w}$ grupach), odgrywać role społeczne i współpracować z innymi, by osiągnąć jakiś cel. Wyrażają swoje uczucia, kłamią, popełniają błędy i uczą się na nich. Ponadto ludzie wykazują poczucie humoru, komunikują się ze sobą za pomocą opowieści, symboli i metafor, które wymagają wyobraźni, abstrakcyjnego myślenia lub dodatkowej wiedzy, aby odszyfrować ich znaczenie. Jak przekonuje izraelski historyk i myśliciel Yuval Noah Harari ${ }^{19}$ - ludzie bardzo sprawnie posługują się językiem operującym fikcją w celu „wyobrażania sobie i opisywania zjawisk i stanów rzeczy, które nie istnieją poza opowiadanymi [przez nich - przyp. aut.] historiami”20. Innymi słowy - istoty ludzkie dysponują zdolnością tworzenia tzw. rzeczywistości wyobrażonych, czyli mają swoje mity i legendy reprezentujące określone wartości; mają swoje opinie i przekonania, w imię i na rzecz których potrafią działać; umieją wykorzystywać archetypiczne motywy, aby łączyć przeszłość, teraźniejszość i przyszłość. W konsekwencji lista możliwości animizacji produktów i marek może być o wiele dłuższa i zawierać więcej bardziej skomplikowanych rozwiązań niż ruch, dźwięk czy kształt.

${ }^{17}$ D. Gefen, D. Straub, Consumer Trust in B2C e-Commerce and the Importance of Social Presence: Experiments in e-Products and e-Services, „Omega”, 2004, 32(6), s. 407-424; J. Argo, D. Dahl, R. Manchanda, The Influence of a Mere Social Presence in a Retail Context, "Journal of Consumer Research”, 2005, 32(2), s. 207-212; D. Dahl, R. Manchanda, J. Argo, Embarrassment in Consumer Purchase: The Roles of Social Presence and Purchase Familiarity, „Journal of Consumer Research”, 2001, 28(3), s. 473481; R. Schroll, B. Schnurr, D. Grewal, Humanizing Products with Handwritten Typefaces, „Journal of Consumer Research", 2018, DOI: 10.1093/jcr/ucy014.

18 R. Schroll, B. Schnurr, D. Grewal, op.cit.

19 Y.N. Harari, Od zwierząt do bogów. Krótka historia ludzkości, PWN, Warszawa 2016.

${ }^{20}$ Ibidem, s. 47. 
Na podstawie powyższych rozważań można zaproponować co najmniej 7 kategorii wskazówek animizacyjnych dla komunikacji marketingowej marek:

1. Język - zastosowanie bezpośrednich zwrotów do konsumenta oraz słów lub związków wyrazowych charakterystycznych dla świata marki.

Mowa i język to podstawowe środki porozumiewania się istot żywych. Za pomocą słów ludzie komunikują swoje opinie, poglądy oraz porządkują otaczający ich świat. Język spełnia szczególne funkcje identyfikacyjne, tzn. każda osoba ma swój charakterystyczny sposób wyrażania się i formułowania myśli. Tak jak człowiek ma indywidualny styl wysławiania się, tak i marka może dysponować swoim własnym unikalnym repertuarem zwrotów lub pojęć (np. „Mniahaha”, Danio; „Made with M”, M\&M’s; „Chce się Ż”, Żywiec).

2. Opowieści - oparcie przekazu reklamowego na konstrukcji narracyjnej.

Snucie historii jest szczególną umiejętnością ludzi, gdyż umożliwia tworzenie rzeczywistości oraz porządków wyobrażonych ${ }^{21}$. Typowe opowieści podążają za klasyczną strukturą dramatu lub nawiązują swoją budową do modelu bajki magicznej ${ }^{22}$. Zawierają zatem takie elementy, jak m.in.: główny bohater oraz jego oponent, konflikt lub przeszkoda do pokonania, wprowadzenie w problematykę i zawiązanie akcji, punkty zwrotne ${ }^{23}$. Opowieści służą do zaprezentowania kluczowych wartości, wprowadzenia odbiorców w świat i filozofię marki oraz do zobrazowania problemów, które marka rozwiązuje dla swoich konsumentów (np. reklama Allegro pt. „Czego szukasz w święta? English for beginners”).

3. Styl i rola życiowa - manifestacja światopoglądu reprezentowanego przez markę oraz jej skłonności i funkcji społecznych, kulturowych, politycznych i in.

Wszystkie istoty żywe wchodzą w jakieś interakcje z otoczeniem, a w konsekwencji budują różne porządki kulturowe, społeczne, polityczne i/lub ekonomiczne. W ramach tworzonych struktur ludzie (oraz zwierzęta) odgrywają określone role (np. matki, nauczyciela, kumpla, zwierzchnika, ucznia) oraz kształtują swój

${ }^{21}$ Y.N. Harari, op.cit.

22 J. Wasilewski, Opowieści o Polsce - retoryka narracji, Headmade, Warszawa 2012; K. Fog, C. Budtz, P. Munch, S. Blanchette, Storytelling - narracja w reklamie i biznesie, Saatchi \& Saatchi, Warszawa 2013.

23 A.G. Woodside, J.C. Chebat, Updating Heider's balance theory in consumer behavior: a Jewish couple buys a German car and additional buying-consuming transformation stories, „Psychology \& Marketing”, 2001, 18(5), s. 475-495; A.G. Woodside, S. Sood, K. Miller, When Consumers and Brands Talk: Storytelling Theory and Research in Psychology and Marketing, „Psychology \& Marketing”, 2008, 25(2), s. 97-145; A. Merchant, J. Ford, A. Sargeant, Charitable organizations' storytelling influence on donors' emotions and intentions, "Journal of Business Research”, 2010, 63, s. 754-762; W.D. Wells, Lectures and dramas, [w:] Cognitive and affective responses to advertising, red. P. Cafferata, A.M. Tybout, s. 13-20, Lexington 1989. 
indywidualny styl życia, czyli przejawiają swoisty sposób zachowania, spędzania wolnego czasu, a także dokonywania wyborów w zakresie alokacji własnych zasobów ${ }^{24}$. Podobnie jak człowiekowi, również i markom można przypisać określone style oraz role życiowe. Na przykład Lego to kreatywny nauczyciel, Harley Davidson to kumpel w podróży, Red Bull to sportowiec balansujący na granicy ludzkich możliwości, natomiast Toms walczy o wyrównanie szans rozwojowych i wspiera potrzebujących.

4. Humor - zbudowanie wrażenia (na poziomie audiowizualnym lub tekstowym), że reklamowana marka ma poczucie humoru.

Umiejętność wytwarzania i rozumienia humoru jest bardzo charakterystyczna dla ludzi, a nie przyrody nieożywionej. Żartobliwość, poczucie i wyczucie humoru to cechy typowo ludzkie. Odgrywają one niebagatelną rolę w interakcjach społecznych, gdyż ludzie weseli są postrzegani jako bardziej atrakcyjni, zdolni ${ }^{25}$, inteligentni ${ }^{26}$, a także chętniej są wybierani na potencjalnych partnerów lub towarzyszy $^{27}$. Innymi słowy, w stosunkach interpersonalnych preferuje się te osoby, które rozśmieszają, ponieważ oferują wartość dodaną w postaci rozrywki.

Wyposażenie marki w poczucie humoru sprowadza się do ukazania jej w przekazie reklamowym jako obiektu opowiadającego żarty, śmiejącego się z żartów i tworzącego żartobliwe sytuacje. Wiele marek korzysta $z$ tej formuły i chętnie operuje humorem w swoich reklamach. Na przykład Heineken stosuje przeróżne rodzaje humoru w swojej komunikacji marketingowej (od satyry po psikusy sytuacyjne) i stara się nie tylko rozbawić publiczność, lecz także obśmiewać innych, np. celebrytów lub na pozór niczego niespodziewających się konsumentów ${ }^{28}$.

5. Rytuały - zamieszczenie w przekazie informacji na temat konkretnej sekwencji znaczących czynności, które należy wykonać w procesie konsumpcji marki.

${ }^{24}$ M. Solomon, Consumer Behavior. Buying, Having and Being, Pearson Education, Harlow 2018.

${ }^{25}$ E.R. Bressler, T. Balshine, The influence of humor on desirability, „Evolution and Human Behavior", 2006, 27, s. 29-39.

${ }^{26}$ G. Miller, Sexual selection for indicators of intelligence, [w:] The nature of intelligence, red. G. Bock, J. Goode, K. Webb, Novartis Foundation Symposium 233, Wiley, Chichester 2000, s. 260-275; G. Greengross, G. Miller, Humor ability reveals intelligence, predicts mating success, and is higher in males, „Intelligence”, 2011, 39, s. 188-192.

${ }^{27}$ R. Goodwin, Sex differences among partner preferences: Are the sexes really very similar?, „Sex Roles”, 1990, 23, s. 501-513; D. Lundy, J. Tan, M. Cunningham, Heterosexual romantic preferences: The importance of humor and physical attractiveness for different types of relationships, „Personal Relationships", 1998, 5, s. 311-325; S. Sprecher, P. Regan, Liking some things (in some people) more than others: Partner preferences in romantic relationships and friendships, "Journal of Social and Personal Relationships", 2002, 19, s. 463-481.

${ }^{28}$ M. Karpińska-Krakowiak, Kapitat marki w mediach społecznościowych-perspektywa konsumenta, Wydawnictwo Uniwersytetu Łódzkiego, Łódź 2019. 
Rytuał stanowi formę zachowań symbolicznych i pozostaje charakterystyczny dla działań oraz organizacji świata ludzi. Rytuały to powtarzalne grupy czynności o szczególnej wartości indywidualnej, kulturowej i/lub społecznej ${ }^{29}$. Towarzyszą one człowiekowi po to, by nadawać sens ważnym momentom jego życia (zob. rytuały przejścia według Rogera Caillois ${ }^{30}$ ). Konsumpcja marek może podlegać rytualizacji i wielu przedsiębiorców korzysta z tego zabiegu animizacyjnego, aby podnieść znaczenie produktu w oczach konsumenta (np. trzyetapowy rytuał dla Oreo — „przekręć, poliż, zamocz”; rytuał nalewania piwa Stella Artois).

6. Zabawa - konstrukcja przekazu stwarza okazję do nawiązania interakcji $\mathrm{z}$ konsumentem $\mathrm{w}$ formie zabawy lub gry.

Tym, co odróżnia ludzi i zwierzęta od przyrody nieożywionej, jest również zabawa. W ujęciu antropologicznym stanowi ona kategorię życia społeczno-kulturowego i odnosi się do swobodnego, niewymuszonego działania, przeciwstawnego pracy i obowiązkom, realizowanego w czasie wolnym od czynności zawodowych oraz zarobkowych ${ }^{31}$. Granice zabawy zawsze są wyznaczane przez ramy czasowo-przestrzenne, gdyż rozgrywa się ona w określonym czasie (np. kończy i zaczyna na umówiony sygnał) i w wyznaczonej przestrzeni (np. na boisku, w hali sportowej, w parku, na szachownicy). Na potrzeby zabawy konstytuuje się zatem tymczasowy, ograniczony, a także - co należy podkreślić - wtórny świat, zastrzeżony tylko dla uczestników ${ }^{32}$.

Zabawa bywa działaniem podejmowanym w samotności, ale zazwyczaj realizuje się ją w grupie. Pełni ona wówczas ważną rolę społeczną, gdyż, jak podkreśla Caillois, stanowi czynnik „nawiązania kontaktu i zbiorowej przyjemności” ${ }^{33}$. Wspólne przeżywanie, dzielenie przyjemności lub innych doznań czy po prostu chęć porównania swoich umiejętności z umiejętnościami innych staje się dodatkową funkcją zabawy i bodźcem motywującym do udziału w niej.

Na gruncie komunikacji marketingowej zabawa może przybierać różne formy: od prostych konkursów i loterii organizowanych w przestrzeni sklepu lub Internetu po bardziej zaawansowane gry alternatywnej rzeczywistości odbywające się zarówno w świecie cyfrowym, jak i rzeczywistym ${ }^{34}$. Każdy rodzaj zabawy ma

${ }^{29}$ G. McCracken, Culture and consumption: a theoretical account of the structure and movement of the cultural meaning of consumer goods, „Journal of Consumer Research”, 1986, 13, s. 71-84.

${ }^{30}$ R. Caillois, Gry i ludzie, Oficyna Wydawnicza Volumen, Warszawa 1997.

${ }^{31}$ J. Huizinga, Homo ludens. Zabawa jako źródło kultury, Wydawnictwo Czytelnik, Warszawa 1985.

${ }^{32}$ J. Huizinga, op.cit.; R. Caillois, op.cit.

${ }^{33}$ R. Caillois, op.cit., s. 45.

${ }^{34}$ Karpińska-Krakowiak M., Gry rzeczywistości alternatywnej (ARG) w promocji marek — praktyka, wyzwania $i$ efektywność, [w:] Determinanty $i$ efekty wspótczesnej aktywności marketingowej, red. J. Wiażewicz, A. Zielińska, Wydawnictwo Politechniki Rzeszowskiej, Rzeszów 2015, s. 87-96. 
za zadanie nie tylko ustanowić wartościowy kontakt z marką, lecz także zwiększyć jej atrakcyjność w oczach konsumenta.

7. Postać - wykorzystywanie w przekazie reklamowym wizerunku prawdziwej lub fikcyjnej postaci związanej z marką (np. króliczek Duracell) bądź uosabiającej produkt (np. ludzik zbudowany z opon Michelin). W swoich obszernych badaniach nad antropomorfizmem Aggarwal ${ }^{35}$ i McGill ${ }^{36}$ sugerują, że wykorzystanie w reklamie sylwetki człowieka stanowi skuteczny zabieg personifikujący markę. Obecność fikcyjnych lub prawdziwych postaci nadaje marce ludzki wymiar, co w konsekwencji ułatwia konsumentom odnoszenie się do niej ${ }^{37}$. Istnieje wiele różnych możliwości wprowadzenia do przekazu reklamowego postaci ożywionych, m.in.: projektowanie maskotek (np. króliczek z płatków Nesquik), animowanie produktów (drażetki M\&M's z oczami, nogami i mimiką twarzy), prezentacja sławnych osobistości (np. Christina Aguilera i Shaquille O’Neal dla Oreo), legendarnych liderów (np. Anita Roddick, Coco Chanel, Blake Mycoskie, Christian Louboutin) czy regularnych użytkowników produktu (np. rodzice serwujący dzieciom kanapki z nutellą na śniadanie).

\section{PROCEDURA BADAWCZA}

W poszukiwaniu odpowiedzi na pytanie o częstotliwość i formy animizacji marek we współczesnych reklamach przeprowadzono badania na podstawie metody analizy zawartości przekazu (content analysis). Procedurę badawczą zaprojektowano zgodnie ze wskazówkami metodologicznymi wysuniętymi przez Klausa Krippendorffa ${ }^{38}$. Najpierw zbudowano definicję operacyjną animizacji oraz przygotowano listę wskazówek animizacyjnych mieszczących się w obrębie siedmiu zidentyfikowanych powyżej kategorii teoretycznych (tj. język, opowieści, styl i rola życiowa, humor, rytuały, zabawa, postać). Następnie dla każdej wskazówki stworzono pytanie lub grupę pytań, które zamieszczono w kwestionariuszu do kodowania zawartości reklam. Pytania skonstruowano, opierając się na formule binarnej, tzn. 1 oznaczało zastosowanie danego rozwiązania animizacyjnego, a 0 - brak tego rozwiązania w analizowanym przekazie (np. $1=$ „Tak, materiał reklamowy prezentuje powtarzalną sekwencję znaczących czynności, które należy wykonać w procesie konsumpcji marki”, 0 = „Nie, materiał reklamowy nie prezentuje powtarzalnej

${ }^{35}$ P. Aggarwal, The Effects of Brand Relationship Norms on Consumer Attitudes and Behavior, „Journal of Consumer Research", 2004, 31, s. 87-101.

${ }^{36}$ P. Aggarwal, A.L. McGill, op.cit., "Journal of Consumer Research”, 2007, 34(4), s. 468-479; P. Aggarwal, A.L. McGill, op.cit., „Journal of Consumer Research”, 2012, 39(2), s. 307-323.

${ }^{37}$ P. Aggarwal, A.L. McGill, op.cit.

${ }^{38}$ K. Krippendorff, Content analysis - An introduction to its methodology, Sage, Londyn 2013. 
sekwencji znaczących czynności wykonywanych w procesie konsumpcji marki”). Kwestionariusz uwzględniał też trzecią opcję odpowiedzi: „nie jestem pewny/a”; łącznie zawierał ponad 30 pytań kodujących.

Próbę badawczą konstytuowały reklamy telewizyjne z czterech najpopularniejszych kanałów telewizyjnych w Polsce. Przez trzy tygodnie nagrywano wszystkie przerwy reklamowe nadawane $\mathrm{w}$ tych kanałach $\mathrm{w}$ godzinach $20.00-22.00$, tj. w najdroższym czasie antenowym, bo przyciągającym największą liczbę widzów (prime-time). Ze stworzonego w ten sposób zbioru usunięto powtarzające się reklamy, zwiastuny filmów, materiały autopromocyjne oraz informacje o sponsoringu programu. Na ostateczną próbę składało się 159 filmów reklamowych wyprodukowanych przez 122 marki.

Do badań zaproszono dwóch koderów. Przedstawiono im definicję operacyjną animizmu oraz przeszkolono ich w zakresie analizy treści reklamowych w kontekście wykorzystania wskazówek animizacyjnych. Następnie poproszono ich o analizę każdej ze 159 reklam na podstawie opisanego powyżej kwestionariusza kodowania. Rzetelność pracy koderów oceniano wskaźnikiem $\alpha$ Krippendorffa (wartość graniczna $=0,80$ ), a wszelkie rozbieżności były dyskutowane i uzgadniane z trzecim koderem (aby uzyskać całkowitą jednomyślność w wynikach).

\section{REZULTATY ANALIZY ZAWARTOŚCI REKLAM}

W celu przetestowania rzetelności stworzonego instrumentu do pomiaru animizacji wpierw przeprowadzono analizę Rascha za pomocą pakietu Winsteps 4.0. Uzyskano satysfakcjonujące wyniki dopasowania danych do modelu (współczynnik rzetelności pytań wynosił 0,93 przy SD równym 1,22; indeks separacji $=3,59$ ). Wskaźnik INFIT MNSQ pozostawał w akceptowalnym przedziale od 0,75 do 1,36. Ponadto model Rascha pozwolił na wyznaczenie tych pytań w ramach narzędzia pomiarowego, które potencjalnie reprezentowały najwyższą i najniższą trudność dla respondenta (prawdopodobieństwo uzyskania pozytywnego wyniku ${ }^{39}$ ). W niniejszym projekcie „najtrudniejsze” pytanie dotyczyło rytuału $(2,43, \mathrm{SE}=0,72)$, a "najłatwiejsze" - ukazywania wizerunku postaci ludzkich $(-3,33, \mathrm{SE}=0,20)$.

W 89\% reklam (czyli w 142 na 159) zidentyfikowano jakiś zabieg animizacyjny. Najwięcej przekazów, bo aż 83\%, prezentowało ludzkich bohaterów lub fikcyjne postaci o antropomorficznych kształtach i tworzyło nowe zwroty, słowa bądź nawet slang charakterystyczny dla marki (42\%). W próbie było znacząco więcej reklam

${ }^{39}$ J.M. Linacre, What do infit and outfit, mean-square and standardized mean?, „Rasch Measurement Transactions”, 2002, 16, s. 878; J.M. Linacre, Rasch dichotomous model vs. one-parameter logistic model, „Rasch Measurement Transactions”, 2005, 19, s. 1032. 
Tabela 1.1. Częstotliwość występowania wskazówek animizacyjnych pogrupowanych według siedmiu podstawowych kategorii $(n=159)$

\begin{tabular}{|l|c|c|c|}
\hline Wskazówka animizacyjna & Brak & Występuje & $\begin{array}{c}\text { Udział procentowy } \\
\text { reklam z daną wskazówką } \\
\text { animizacyjną }\end{array}$ \\
\hline postać & 27 & 132 & $83 \%$ \\
\hline język & 92 & 67 & $42 \%$ \\
\hline styl i rola życiowa & 115 & 44 & $28 \%$ \\
\hline humor & 125 & 34 & $21 \%$ \\
\hline opowieść & 126 & 33 & $21 \%$ \\
\hline rytuał & 137 & 22 & $44 \%$ \\
\hline zabawa & 153 & 6 & $36 \%$ \\
\hline $\begin{array}{l}>2 \text { wskazówki } \\
\text { animizacyjne jednocześnie }\end{array}$ & 102 & 57 & $4 \%$ \\
\hline
\end{tabular}

Źródto: opracowanie własne.

zawierających (niż niezawierających) te dwie wskazówki animizacyjne $\left(\chi^{2}=3,67\right.$, $\mathrm{p}=0,05$ ). Pozostałe rozwiązania mające na celu ożywienie marki (styl i rola życiowa, humor, opowieści, rytuał) były rzadziej stosowane i występowały w ok. 20\% przekazów. Zaobserwowano jedynie 6 reklam podejmujących próbę animizacji przez wykorzystanie wątków związanych z zabawą (por. tabela 1.1).

Tabela 1.2. Częstotliwość stosowania wskazówek animizacyjnych w reklamie - analiza korespondencji $(n=159)$

\begin{tabular}{|c|c|c|c|c|}
\hline \multirow{2}{*}{\multicolumn{2}{|c|}{ Poszczególne wskazówki animizacyjne }} & \multicolumn{2}{|c|}{$\begin{array}{c}\text { Animizacja ogólna } \\
\text { (>2 wskazówki animizacyjne } \\
\text { jednocześnie) }\end{array}$} & \multirow{2}{*}{$\chi^{2}$} \\
\hline & & $\begin{array}{c}\text { brak } \\
(n=102)\end{array}$ & $\begin{array}{c}\text { występuje } \\
(n=57)\end{array}$ & \\
\hline \multirow{2}{*}{ postać } & brak $(n=27)$ & 24 & 3 & \multirow{2}{*}{$\begin{array}{c}8,65 \\
p<0,01\end{array}$} \\
\hline & występuje $(n=132)$ & 78 & 54 & \\
\hline \multirow{2}{*}{ język } & $\operatorname{brak}(n=92)$ & 80 & 12 & \multirow{2}{*}{$\begin{array}{c}49,37 \\
p<0,01\end{array}$} \\
\hline & występuje (n=67) & 22 & 45 & \\
\hline \multirow{2}{*}{ styl i rola życiowa } & brak $(n=115)$ & 100 & 15 & \multirow{2}{*}{$\begin{array}{c}93,98 \\
p<0,01\end{array}$} \\
\hline & występuje $(n=44)$ & 2 & 42 & \\
\hline
\end{tabular}




\begin{tabular}{|c|c|c|c|c|}
\hline \multirow{2}{*}{\multicolumn{2}{|c|}{ Poszczególne wskazówki animizacyjne }} & \multicolumn{2}{|c|}{$\begin{array}{c}\text { Animizacja ogólna } \\
\text { (>2 wskazówki animizacyjne } \\
\text { jednocześnie) }\end{array}$} & \multirow[t]{2}{*}{$\chi^{2}$} \\
\hline & & $\begin{array}{c}\text { brak } \\
(n=102)\end{array}$ & $\begin{array}{c}\text { występuje } \\
(n=57)\end{array}$ & \\
\hline \multirow{2}{*}{ humor } & brak $(n=125)$ & 99 & 26 & \multirow{2}{*}{$\begin{array}{c}57,56 \\
p<0,01\end{array}$} \\
\hline & występuje ( $n=34)$ & 3 & 31 & \\
\hline \multirow{2}{*}{ opowieść } & $\operatorname{brak}(n=126)$ & 93 & 33 & \multirow{2}{*}{$\begin{array}{c}24,62 \\
p<0,01\end{array}$} \\
\hline & występuje ( $n=33)$ & 9 & 24 & \\
\hline \multirow{2}{*}{ rytuał } & brak $(n=137)$ & 99 & 38 & \multirow{2}{*}{$\begin{array}{c}28,33 \\
p<0,01\end{array}$} \\
\hline & występuje ( $n=22)$ & 3 & 19 & \\
\hline \multirow{2}{*}{ zabawa } & brak $(n=153)$ & 100 & 53 & \multirow{2}{*}{$\begin{array}{c}2,57 \\
p=0,11\end{array}$} \\
\hline & występuje $(n=6)$ & 2 & 4 & \\
\hline
\end{tabular}

Źródło: opracowanie własne.

Komunikaty reklamowe tworzy się zazwyczaj na podstawie kilku zabiegów perswazyjnych jednocześnie. W niniejszym badaniu zidentyfikowano 35 reklam, które wykorzystywały po dwie wskazówki animizacyjne oraz 57 reklam z co najmniej trzema takimi rozwiązaniami (co stanowi 36\% próby). W ostatniej wymienionej grupie najczęściej występowały kategorie „język” i „postać” w połączeniu ze „stylem i rolą życiową” oraz „humorem” (por. tabela 1.2).

\section{WNIOSKI}

W ujęciu tradycyjnym animizacja oznacza wprowadzenie do treści reklamowych takich rozwiązań graficznych i/lub tekstowych, które wykorzystują ruch, dźwięk bądź antropomorficzny kształt. Tak pojmowana animizacja jest bardzo silnie obecna we współczesnej reklamie, bo ponad 130 z badanych 159 filmów prezentowało jakąś formę ludzkiej postaci (a dokładniej: 100 ukazywało zwykłych ludzi, 23 - fikcyjnych, animowanych bohaterów, a 35 - celebrytów). Reklamodawcy mogą korzystać też z bardziej nowoczesnych form sugerowania konsumentom, że prezentowane w przekazach promocyjnych marki żyją. Animizacja bowiem może następować przez stworzenie wrażenia obecności istoty żywej, bez konieczności nadawania marce fizycznych cech typowych dla obiektów ożywionych. W rezultacie twórcy reklam mają do dyspozycji o wiele więcej możliwości i mogą wykorzystywać wskazówki animizacyjne oparte na humorze, rytuałach, zabawie, 
opowieściach lub przypisywać im specyficzne role społeczne, a także style życia. Takie zabiegi nie są bardzo rozpowszechnione (występowały w ok. 20\% poddanych analizie przekazów), lecz mają szansę zyskać większą popularność, jeśli okażą się skuteczne w generowaniu pożądanych reakcji kognitywnych i afektywnych wśród konsumentów. Tego rodzaju zależności nie były przedmiotem niniejszych badań, ale stanowią niezwykle ciekawe wyzwanie badawcze na przyszłość.

\section{BIBLIOGRAFIA}

Aggarwal P., The Effects of Brand Relationship Norms on Consumer Attitudes and Behavior, „Journal of Consumer Research", 2004, 31, s. 87-101.

Aggarwal P., McGill A.L., When Brands Seem Human, Do Humans Act Like Brands? Automatic Behavioral Priming Effects of Brand Anthropomorphism, "Journal of Consumer Research”, 2012, 39(2), s. 307-323.

Aggarwal P., McGill A.L., Is That Car Smiling at Me? Schema Congruity as a Basis for Evaluating Anthropomorphized Products, „Journal of Consumer Research”, 2007, 34(4), s. 468-479.

Argo J., Dahl D., Manchanda R., The Influence of a Mere Social Presence in a Retail Context, „Journal of Consumer Research", 2005, 32(2), s. 207-212.

Avis M., Anthropomorphism and Animism Theory in Branding, „Asia-Pacific Advances in Consumer Research", 2011, 9, s. 313-319.

Bressler E.R., Balshine T., The influence of humor on desirability, „Evolution and Human Behavior”, 2006, 27, s. 29-39.

Bullock M., Animism in childhood thinking: a new look at an old question, „Developmental Psychology", 1985, 21, s. 217-225.

Caillois R., Gry i ludzie, Oficyna Wydawnicza Volumen, Warszawa 1997.

Dahl D., Manchanda R., Argo J., Embarrassment in Consumer Purchase: The Roles of Social Presence and Purchase Familiarity, „Journal of Consumer Research”, 2001, 28(3), s. 473-481.

De Bondt C., Van Kerckhove A., Geuens M., Look at that body! How anthropomorphic package shapes systematically appeal to consumers, „International Journal of Advertising”, 2018, DOI: 10.1080/02650487.2018.1470919.

Delbaere M., McQuarrie E., Phillips B., Personification in Advertising: Using a Visual Metaphor to Trigger Anthropomorphism, „Journal of Advertising”, 2011, 40, s. 121-130.

Epley N., Waytz A., Cacioppo J., On Seeing Human: A Three-Factor Theory of Anthropomorphism, „Psychological Review”, 2007, 114(4), s. 864-886.

Fog K., Budtz C., Munch P., Blanchette S., Storytelling - narracja w reklamie i biznesie, Saatchi \& Saatchi, Warszawa 2013.

Fournier S., Consumers and their brands: Developing relationship theory in consumer research, „Journal of Consumer Research", 1998, 24(3), s. 343-373.

Gefen D., Straub D., Consumer Trust in B2C e-Commerce and the Importance of Social Presence: Experiments in e-Products and e-Services, „Omega”, 2004, 32(6), s. 407-424.

Goodwin R., Sex differences among partner preferences: Are the sexes really very similar?, „Sex Roles”, 1990, 23, s. 501-513.

Graham S., Poulin-Dubois D., Infants' Reliance on Shape to Generalize Novel Labels to Animate and Inanimate Objects, „Journal of Child Language”, 1999, 26(2), s. 295-320.

Greengross G., Miller G., Humor ability reveals intelligence, predicts mating success, and is higher in males, „Intelligence”, 2011, 39, s. 188-192. 
Guthrie S., Faces in the clouds, Oxford University Press, 1993.

Guthrie S., Bottles are men, glasses are women: religion, gender, and secular objects, „Material Religion”, 2007, 3(1), s. 14-33.

Harari Y.N., Od zwierząt do bogów. Krótka historia ludzkości, PWN, Warszawa 2016.

Huizinga J., Homo ludens. Zabawa jako źródło kultury, Wydawnictwo Czytelnik, Warszawa 1985.

Inagaki K., Sugiyama K., Attributing human characteristics: developmental changes in over- and underattribution, „Cognitive Development”, 1988, 3, s. 55-70.

Karpińska-Krakowiak M., Gry rzeczywistości alternatywnej (ARG) w promocji marek - praktyka, wyzwania i efektywność, [w:] Determinanty i efekty wspótczesnej aktywności marketingowej, red. J. Wiażewicz, A. Zielińska, Wydawnictwo Politechniki Rzeszowskiej, Rzeszów 2015, s. 87-96.

Karpińska-Krakowiak M., Kapitat marki w mediach społecznościowych - perspektywa konsumenta, Wydawnictwo Uniwersytetu Łódzkiego, Łódź 2019.

Krippendorff K., Content analysis - An introduction to its methodology, Sage, Londyn 2013.

Linacre J.M., What do infit and outfit, mean-square and standardized mean?, „Rasch Measurement Transactions", 2002, 16, s. 878.

Linacre J.M., Rasch dichotomous model vs. one-parameter logistic model, „Rasch Measurement Transactions", 2005, 19, s. 1032.

Lundy D., Tan J., Cunningham M., Heterosexual romantic preferences: The importance of humor and physical attractiveness for different types of relationships, „Personal Relationships”, 1998, 5, s. 311-325.

Maeng A., Aggarwal P., Facing Dominance: Anthropomorphism and the Effect of Product Face Ratio on Consumer Preference, ,Journal of Consumer Research”, 2017, 44(5), s. 1104-1122.

McCracken G., Culture and consumption: a theoretical account of the structure and movement of the cultural meaning of consumer goods, „Journal of Consumer Research”, 1986, 13, s. 71-84.

McDonald L., Stuart-Hamilton I., The Meaning of Life: Animism in the Classificatory Skills of Older Adults, „International Journal of Aging and Human Development”, 2000, 51(3), s. 231-242.

Merchant A., Ford J., Sargeant A., Charitable organizations' storytelling influence on donors' emotions and intentions, „Journal of Business Research”, 2010, 63, s. 754-762.

Miller G., Sexual selection for indicators of intelligence, [w:] The nature of intelligence, red. G. Bock, J. Goode, K. Webb, Novartis Foundation Symposium 233, Wiley, Chichester 2000, s. 260-275.

Morewedge C., Preston J., Wegner D., Timescale Anthropomorphism in the Attribution of Mind, [working paper], Harvard University, Boston 2004.

Parry R., Stuart-Hamilton I., Animism begins at forty: evidence that animism and other naive beliefs are established before the onset of old age, „Educational Gerontology”, 2010, 36, s. 1043-1050.

Piaget J., The Child's Conception of the World, Harcourt Brace, Nowy Jork 1929.

Piaget J., The Child's Conception of the World, Routledge and Kegan Paul, Londyn 1951.

Puzakova M., Aggarwal P., Brands as Rivals: Consumer Pursuit of Distinctiveness and the Role of Brand Anthropomorphism, ,Journal of Consumer Research”, 2018, na podstawie: https://doi. org/10.1093/jcr/ucy035 (dostęp: 29.01.2019).

Puzakova M., Kwak H., Should Anthropomorphized Brands Engage Customers? The Impact of Social Crowding on Brand Preferences, „Journal of Marketing”, 2017, 81(6), s. 99-115.

Puzakova M., Kwak H., Rocereto J., Pushing the Envelope of Brand and Personality: Antecedents and Moderators of Anthropomorphized Brands, „Advances in Consumer Research”, 2009, 36, S. $413-419$.

Schroll R., Schnurr B., Grewal D., Humanizing Products with Handwritten Typefaces, „Journal of Consumer Research", 2018, na podstawie: https://doi.org/10.1093/jcr/ucy014 (dostęp: 11.02.2019).

Solomon M., Consumer Behavior. Buying, Having and Being, Pearson Education, Harlow 2018. 
Sprecher S., Regan P., Liking some things (in some people) more than others: Partner preferences in romantic relationships and friendships, "Journal of Social and Personal Relationships", 2002, 19, s. 463-481.

Tremoulet P., Feldman J., Perception of Animacy from the Motion of a Single Object, „Perception”, 2000, 29(8), s. 943-951.

Wasilewski J., Opowieści o Polsce - retoryka narracji, Headmade, Warszawa 2012.

Wells W.D., Lectures and dramas, [w:] Cognitive and affective responses to advertising, red. P. Cafferata, A.M. Tybout, s. 13-20, Lexington 1989.

Willerslev R., Not animal, not not-animal: hunting, imitation and empathetic knowledge among the Siberian Yukaghirs, "Journal of the Royal Anthropological Institute”, 2004, 10(3), s. 629-652.

Woodside A.G., Chebat J.C., Updating Heider's balance theory in consumer behavior: a Jewish couple buys a German car and additional buying-consuming transformation stories, „Psychology \& Marketing”, 2001, 18(5), s. 475-495.

Woodside A.G., Sood S., Miller K., When Consumers and Brands Talk: Storytelling Theory and Research in Psychology and Marketing, „Psychology \& Marketing”, 2008, 25(2), s. 97-145.

\section{STRESZCZENIE}

Celem zaprezentowanych w niniejszym tekście badań była konceptualizacja animizacji oraz wskazówek animizacyjnych, a następnie oszacowanie częstotliwości stosowania tych zabiegów narracyjnych w przekazach reklamowych. Badania przeprowadzono, opierając się na metodzie analizy zawartości przekazu i przeanalizowano łącznie 159 filmów reklamowych wyprodukowanych przez 122 marki. Wyniki mogą być przydatne nie tylko dla naukowców, lecz także dla przedsiębiorców dążących do stosowania animizacji w swoich reklamach.

\section{Słowa kluczowe}

animizacja, animizm, reklama, zarządzanie marką

\section{ABSTRACT}

The idea behind the current study was to conceptualize animistic techniques and to estimate how frequently they are used nowadays in advertising messages. In an attempt to reach this goal, content analysis was performed and 159 advertising films (produced by 122 brands) were analyzed. The results provide important implications not only to scholars, but also to marketing practitioners.

\section{Key words}

animism, animation, advertising, brand management 


\section{BIOGRAM}

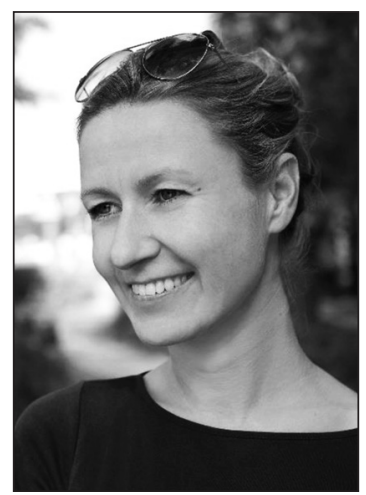

Dr hab. Małgorzata Karpińska-Krakowiak pracuje w Katedrze Marketingu Międzynarodowego i Dystrybucji na Uniwersytecie Łódzkim oraz w Katedrze Marketingu na Uniwersytecie Europejskim Viadrina we Frankfurcie. Zajmuje się problematyką skuteczności komunikacji marketingowej i predykcji zachowań konsumentów. Wielokrotna stypendystka Niemieckiej Centrali Wymiany Akademickiej (DAAD), stała współpracowniczka Centrum Badawczego nad Sztuczną Inteligencją (CSAI) przy Uniwersytecie Bicocca w Mediolanie oraz Centrum Badawczego nad Komunikacją Marketingową (CMC) przy Europejskim Uniwersytecie Viadrina we Frankfurcie. Jej publikacje ukazały się m.in. w takich prestiżowych czasopismach, jak „International Journal of Advertising”, „Journal of Advertising Research” czy „Journal of Computer Information Systems”. Oprócz naukowego posiada również doświadczenie biznesowe - przez 10 lat pracowała w agencji reklamowej, w której była odpowiedzialna za prowadzenie projektów dla największych polskich i międzynarodowych marek, np. Masterfoods, Nestlé, Storck, Heinz, Vision Express, Colgate-Palmolive, Wyborowa, Kimberly Clark. 